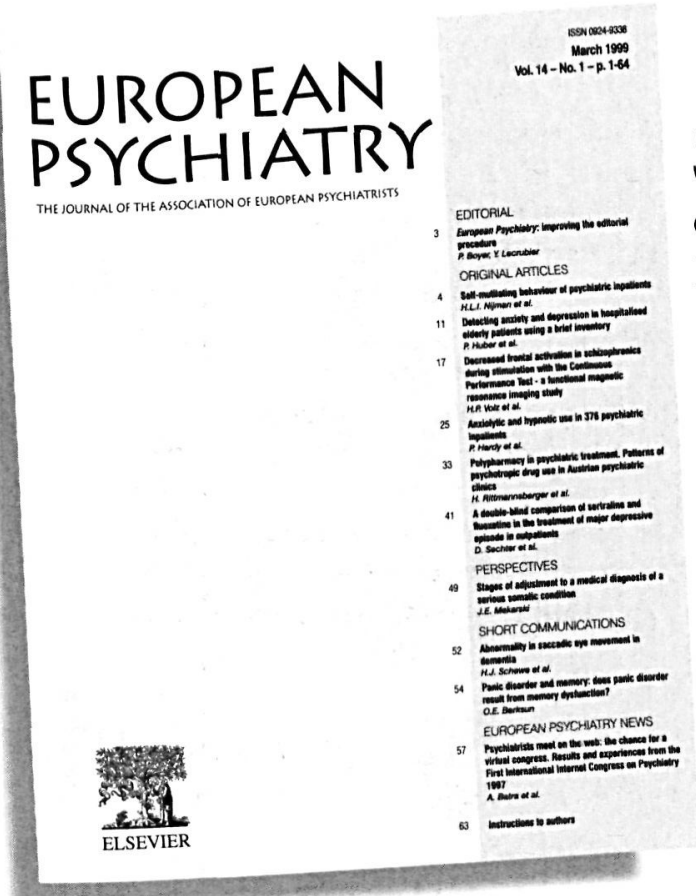

Since 1991, European Psychiatry has been the official journal of the Association of European Psychiatrists (AEP).

European Psychiatry presents the results of original research relative to those numerous diverse fields currently of interest to psychiatrists: psychopathology, nosography, chemotherapy, psychotherapy, clinical methodology, biological disorders and mental pathology, psychophysiology, neuropsychophysiology, relative to therapeutics, clinical and basic research as well as animal behaviour. This wide scope is aimed at encouraging the exchange of ideas and research within Europe and establishing within the international psychiatric community an improved level of scientific communication.

European Psychiatry endeavours to publish not only high scientific level original articles, short communications, editorials, letters to the Editor but also AEP newsletters, book reviews, information on new regulations in Europe and a conference calendar. Supplements are also devoted to specific symposia.

\section{Submission of manuscripts}

should be made to the Editors-in-Chief. Instructions to authors are available upon request from the secretariat: European Psychiatry, Hôpital de la Salpêtrière, Pavillon Clérambault, 47, bd de l'Hôpital, 75651 Paris cedex 13, France. Fax no.: (33) 0145852800.
Editors-in-Chief

P. Boyer

Paris, France

Y. Lecrubier

Paris, France

\section{Editors Emeritus}

C. Ballus

Barcelona, Spain

H. Heimann

Tübingen, Germany

\section{Editors}

J.D. Guelfi

Paris, France

R. Murray

London, United Kingdom

M. Maj

Naples, Italy

C.B. Pull

Luxembourg

M. Ackenheil

Munich, Germany

P. Bech

Copenhagen, Denmark

\section{Indexed in}

BIOSIS/Biological Abstracts,

Current Contents/Clinical

Medicine and Social \&

Behavioural Sciences,

EMBASE/Excerpta Medica,

MEDLINE/Index Medicus,

PASCAL/INIST-CNRS,

Psychological Abstracts,

PsycINFO, PsycLIT, Research

Alert, SciSearch

\section{Subscribe today} by far (33) 0145589424

EUROPEAN PSYCHIATRY - 1999 - Volume 14 in 8 issues - ISSN 0924-9338

Please,

Please, send to: Elsevier Subscription Department 23, rue Linois

75724 Paris cedex 15, France

in North, Central and South America:

Please send the order form to the Paris address,

but draw and send a check in US \$ to

Éditions Elsevier P.O. Box 7247-7576

Editions Elsevier P.O. Box 7247-7576

Please make check payable to Éditions Elsevier

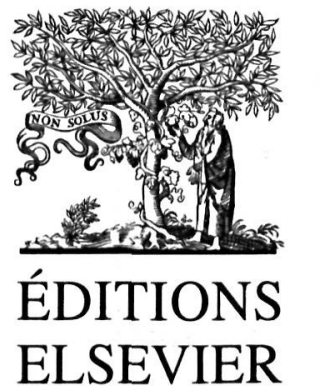

A member of Elsevier Science

http://www.elsevier.fr

Éditions scientifiques et médicales Elsevier

SAS au capital de 80250000 F - 399113877 RCS Paris

$\square$ enter my 1999 subscription to EUROPEAN PSYCHIATRY

Individuals** Institution

European Union*: $\square$ FF 1,105 (€ 168.46) $\square$ FF 2,460 (€ 375.02)

France: $\square \mathrm{FF} \quad 945(€ 144.06) \quad \square \mathrm{FF} 2,290(€ 349.11)$

Rest of the world: $\square$ FF 1,180 (€ 179.89) $\square$ FF 2,860 (€ 436.00)

North, Central \& South America:

$\square$ US $\$ 483$

All prices include taxes (except for countries outside the E.U.), postage and handling.

$\square$ find my check enclosed payable to Éditions Elsevier

$\square$ debit my credit card (CB, EuroCard, MasterCard or Visa). Total amount of order:

No. $L \perp \perp|||| \perp|||||||\perp|$ Expires $L \perp \perp \perp \mid$ Signature:

$\square$ send me an invoice

$\square$ send me a free sample copy
A special rate is available to the members of the Association of European Psychiatrists

\begin{tabular}{ll} 
& SURNAME \\
\hline TITLE & FPME \\
\hline
\end{tabular}




\section{Elsevier Science on the Internet}

Your comprehensive and easy-to-use guide to the world-wide range of Elsevier Science products and services.
Visit Elsevier Science

on the Internet and access

a unique repository of

information covering the

entire scientific spectrum.

Our time-saving search

facilities will lead you

to our frequent updates

in seconds.
Main features include:

Alerting and awareness facilities for new and forthcoming publications.

Fast, time-saving search facilities.

Frequent updates. httpa//umurelsevier.com

httpi/humw-elseviernl

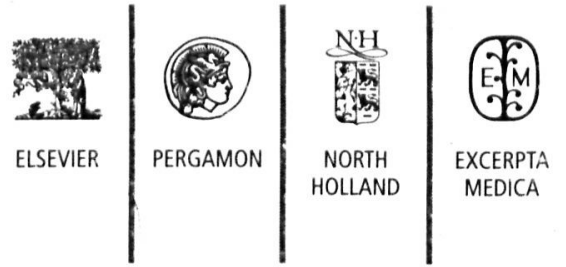

